\title{
EFL Instructors and Learners' Perceptions towards Utilization of Online Applications at Palestine Ahliya University and Hebron University ${ }^{i}$
}

\author{
Mahmoud Itmeizeh ${ }^{1, *}$, Mohammed Farrah² \\ ${ }^{1}$ Department of Languages, Palestine Ahliya University, Bethlehem, Palestine \\ ${ }^{2}$ Department of English, Faculty of Arts, Hebron University, Palestine
}

Received October 11, 2020; Revised January 1, 2021; Accepted January 20, 2021

\section{Cite This Paper in the following Citation Styles}

(a): [1] Mahmoud Itmeizeh, Mohammed Farrah, "EFL Instructors and Learners' Perceptions towards Utilization of Online Applications at Palestine Ahliya University and Hebron University," Universal Journal of Educational Research, Vol. 9, No. 2, pp. 261 - 270, 2021. DOI: 10.13189/ujer.2021.090201.

(b): Mahmoud Itmeizeh, Mohammed Farrah (2021). EFL Instructors and Learners' Perceptions towards Utilization of Online Applications at Palestine Ahliya University and Hebron University. Universal Journal of Educational Research, 9(2), 261 - 270. DOI: 10.13189/ujer.2021.090201.

Copyright $(2021$ by authors, all rights reserved. Authors agree that this article remains permanently open access under the terms of the Creative Commons Attribution License 4.0 International License

\begin{abstract}
After the spread of the Pandemic COVID-19, all educational institutions worldwide shifted to online learning utilizing varied online applications to hold virtual meetings instead of face-to-face ones. Therefore, Palestinian universities used different applications synchronously and asynchronously to manage this sudden and unexpected switch from completely face-to-face mode to an online one. The study aims to investigate the extent to which the online applications utilized in Palestine Ahliya University and Hebron University met the agreed-upon benchmarks of online mode. It also aimed at investigating EFL instructors' and learners' perceptions of online education and the challenges that both of them may face. The sample of the study consisted of 139 students (27 males \& 112 females), and 32 instructors (19 males \& 13 females) from both universities. Regarding the harmony between participants' responses and the online agreed-upon benchmarks, results showed that all instructors' responses scored high degrees of agreement while the students' ones scored medium degrees. EFL learners' and instructors' perceptions towards the utilization of some web applications scored medium degrees though some of the questionnaire items scored high degrees. No statistically significant differences were traced due to all variables except for the variable 'Student Support Benchmark' in favor of the instructors who are aged from 40-50. There are also statistically significant differences between the means
\end{abstract}

of instructors' responses in the domain 'Student Support' in favor of Palestine Ahliya University while other domains show no statistically significant differences between both universities. Some conclusions and recommendations were concluded at the end of the study.

Keywords ZOOM, Moodle, Google Classroom, Google Meet

\section{Introduction}

Since the emergence of online learning, many educational institutions have used a variety of internet applications in the process of teaching and learning. However, the utilization of these applications was restricted to some educational institutions in the world in general, and open universities in particular. After the spread of the Pandemic COVID-19, many educational institutions all over the world rushed to use online learning by adopting different online applications that enable institutions to hold virtual meetings instead of face-to-face ones. As part of this globe, Palestinian universities used different applications using synchronous and asynchronous modes to teach their students online. At the heart of this process, there have been varied views and 
attitudes towards the utility and effectiveness of online learning at Palestinian universities. Some views do support online learning, focusing on its advantages, while others questioned its effectiveness. This debate lacks logic and scientific background. Therefore, the researchers decided to conduct this study that may result in reliable findings based on scientific research, rather than arbitrary judgments and opinions. This research will be limited to the online applications used at Palestine Ahliya University and Hebron University. Palestine Ahliya University adopted ZOOM and Moodle applications, while Hebron University used Google Meet and Google Classroom. The researchers tend to identify the effectiveness of these online applications against some agreed-upon benchmarks that assure their quality and validity. In this study, the researchers will also try to examine the extent to which the agreed-upon benchmarks are met by both universities while utilizing online applications. Moreover, researchers seek to determine EFL instructors' and learners' perceptions of integrating online components into the process of teaching and learning. Finally, the study will also investigate if there are any statistically significant differences between participants' responses due to the study variables (gender, university, age, year of study).

Since the emergence of distance education, online learning and teaching in Palestine can be classified as one of the most controversial issues between those who support face-to-face teaching and those who advocate online teaching. Since then, many Palestinian educational institutions have adopted distance learning. Therefore, Al-Quds Open University was the first Palestinian university to initiate distance learning through designing curricula specially tailored for personalized instruction [1]. Gradually, the university started using some e-learning platforms and applications such as Illuminate, Moodle, Blackboard, etc. After 2000, many other Palestinian universities adopted varied web applications and e-learning platforms as a supplementary tool to face-to-face mode. Some other universities adopted blended learning to teach some courses. This modest utilization of technology in the process of teaching and learning continued until the spread of Coronavirus (COVID-19) in Palestine on March 5th, 2020. This dramatic moment marks the emergence of a new era in the history of education in both Palestine and worldwide. In this era, the whole educational system drastically shifted from face-to-face mode to complete online mode. This sudden transfer imposed additional burdens on most Palestinian universities at the very beginning of the process. Nevertheless, all Palestinian universities in general, and Palestine Ahliya University and Hebron University at the southern part of the West Bank in particular, swiftly managed this critical stage by utilizing some online applications. Palestine Ahliya University used ZOOM and Moodle While Hebron University used Google Meet and Google Classroom.
ZOOM is an application that provides video communications, audio conferencing, chat, video, and webinars. ZOOM enables users to join meetings by entering a meeting ID or by just having the link. Users can also schedule and start their instant meetings or classes by inviting others by sending the link or the ID of the meeting. In these meetings, users can share content with others, change video display layout, display active speakers, show all attendees in grid, view and manage meeting participants, view meeting chat messages, start recording the meeting, leave the meeting or end the meeting as a host, make other participants as co-hosts, invite others to the meeting and use the White Board to write or draw anything [2].

Moodle stands for Modular Object-Oriented Dynamic Learning Environment. Moodle is a course management system that was created to provide academicians, administrators, and students with a free open-source platform to mainly personalize the process of teaching and learning. Users can upload their materials such as printed files, recordings, videos, etc. They can also design their activities, assignments, and e-quizzes. Moodle enables users to select different types of tests such as true/false, multiple-choice, matching, essay questions, short answer questions, drag and drop, and embedded answers. Students can receive immediate verbal and quantitative feedback on their work [3].

Google Classroom is part of the Google Apps for Education suite of tools and is only available to Google Apps for Education accounts. It is designed to help teachers and students communicate and collaborate, manage assignments paperlessly, and stay organized. Google Classroom helps instructors to manage the classroom easily. Instructors can create classes, make assignments, post materials, give quizzes, and grade students [4].

Google Meet supports video calls for up to hundreds of participants. Instructors can host video calls and invite their students to participate, present, record sessions, and moderate either text or audio-based discussions. Instructors and students can connect to teach and learn through email, chat, and video. They collaborate and communicate anywhere [5].

\section{Pertinent Studies}

Reference [6] investigated the impact of a ZOOM session as a synchronous learning strategy on enhancing the engagement, success, and motivation of Lebanese University students in Bekaa. The researcher used a pretest-posttest design to measure the change in the levels of EFL students. A student questionnaire to examine the attitude of the students towards the ZOOM sessions was also used. Findings indicated that ZOOM sessions enhanced EFL students' English language level and 
motivation.

Reference [7] conducted a study to identify various Internet-Based Applications integrated into English as a foreign language (EFL) classroom. It investigated the use of Kahoot, Socrative, Google Form, QR code, Facebook, YouTube, Quizizz, and Quizlet by EFL instructors in teaching English to university students in Thailand. Findings showed that EFL instructors responded positively to changes triggered by the integration of these applications in their classrooms. Results showed the participants' confidence in the advantages of these applications to their teaching practices. Additionally, results reported that Internet-based applications make ELT classrooms more exciting, fluid, and convenient.

Reference [8] investigated the impact of synchronous and asynchronous e-feedback on Lebanese EFL university students' writing skills. Thirty-four learners participated in this study. A pretest and post-test were administered before and after the experiment. A questionnaire, writing tasks, and semi-structured interviews were used for collecting quantitative and qualitative data. Findings revealed that the asynchronous approach of providing e-feedback proved to be more effective in improving the quality of writing of learners.

Reference [9] published a paper to discuss the platforms and languages that can be used by English educators to create new online learning activities. Many web applications developed by the author were briefly examined. In the second part of the paper, a range of theoretical underpinnings for language learning applications are considered, including structuralist, communicative, and interactional viewpoints. The paper concludes with an invitation to English language educators to create their web applications using sound theoretical principles and technological practices.

Reference [10] conducted a study that aimed at investigating the usefulness of Facebook for EFL university students taking an advanced writing class. A questionnaire, an interview, and observation were used for data collection. Findings showed significant improvement in students writing, and learners became more confident in themselves. This study suggests that Facebook can be used as a supplementary learning tool in higher education classrooms.

Reference [11] investigated the findings of 87 pivotal social media services (Blogs, wikis, and social networking) published between 2009 and mid-2018. Analysis of data collected showed that social media can develop intercultural, sociopragmatic aspects in addition to raising students' awareness.

Reference [12] conducted a study titled 'Effective use of ZOOM technology and instructional videos to improve engagement and success of distance students in Engineering'. The study aims to investigate the effectiveness of using the ZOOM application in evening tutorial meetings in improving the students' success in foundation engineering. In this study, students' engagement with the course was measured by observing the types and the number of posts to the Q\&A Forum on the Moodle site for the academic year 2016/2017. The researcher also observed the number of students joining ZOOM virtual tutorials introduced in 2017. Data collected from the Moodle site over the 2016 and 2017 course showed that levels of engagement were preserved with the learning resources. The introduction of ZOOM virtual tutorials resulted in a high degree of students' satisfaction and a decline in instructors' workload of about $25 \%$. By offering online ZOOM tutorials, the number of questions and answers posted on Moodle has declined significantly and reduced the workload of academics without reducing the engagement levels of students or changing the grade distribution.

Reference [13] conducted a study titled 'Skype In The English Language Classroom' This study was conducted on 56 secondary school students from Kubang Pasu District. The students were all studying the same subject and they were exposed to the application of SKYPE. A questionnaire was used to collect data. The findings provided evidence that SKYPE is beneficial and effective for the teaching and learning of English. Thus, teachers and learners could tap their potential to encourage and improve the teaching and learning process.

Reference [14] investigated the usage and practices of the internet in the process of learning the English language by Esfahan University of Technology (B.A.). For this purpose, a questionnaire was administered to a sample of 100 bachelor students at the Esfahan University of Technology. Results indicated that the use of the internet in classrooms is still limited. Students like to use the internet, but teachers do not encourage them. Additionally, although the internet manifests itself as a useful English language learning tool, they still need proof for educationalists, practitioners, teachers, and decision-makers.

Reference [15] evaluated online English for academic writing program using the IHEP 2000 quality agreed-upon benchmarks. According to the instructors, the program met teaching and learning, and course structure agreed-upon benchmarks. However, it did not meet the quality standards for course development, student support, evaluation and assessment, faculty support, and institutional support. On the other hand, the students reported that the program met all of the agreed-upon benchmarks except for student support.

Reference [16] evaluated an online English for Academic Writing course taught at a public university in Malaysia. It also traced the reaction of the institution to the findings. The adapted version of the Institute of Higher Education Policy (IHEP 2000) benchmarks was used to determine if the course met the quality benchmarks for online learning. Interviews with the teachers were used to collect data. Results showed weak 
support to teachers and that they need to manage online mode more appropriately. The study also showed that evaluating online mode needs a longer period of time.

\section{Significance of the Study}

Results of the study are supposed to make the academic and administrative team at Palestinian universities more aware of the agreed-upon benchmarks they really need to meet when they utilize online learning. It is also highly significant and timely as it concerns two universities in Palestine. Moreover, EFL instructors, EFL learners, parents, and university administrators will become more aware of the appropriate utilization of technology in the teaching and learning process. The study will also highlight the extent to which online learning is in harmony with the agreed-upon benchmarks and investigate whether there are any statistically significant differences between participants' responses due to the study variables (gender, university, age, year of study).

\section{Questions of the Study}

- To what extent did the online applications utilized in both universities meet the agreed-upon benchmarks of online learning as perceived by instructors and students?

- To what extent do the items in each domain meet the agreed-upon benchmarks of online learning?

- How do EFL instructors and learners perceive the integration of online components into the process of teaching and learning?

- Are there any statistically significant differences at the level of significance $(\alpha \leq 0.05)$ in the instructors' responses due to gender, university, and age?

- Are there any statistically significant differences at the level of significance $(\alpha \leq 0.05)$ in the students' responses due to university, gender, and year of study?

\section{Methodology}

Adopting the analytical descriptive approach, the researchers used two questionnaires in this study. The first questionnaire targeted EFL instructors containing some agreed-upon benchmarks necessary for the success of any online learning (Teaching Process, Student Support, Evaluation and Assessment, Faculty Support). In addition to these four domains, a fifth domain that investigates instructors' perceptions was incorporated into the questionnaire. The second questionnaire targeted EFL learners focusing on some agreed-upon benchmarks of online learning (Learning Process, Student Support,
Evaluation, and Assessment). A fourth domain was also added to investigate learners' perceptions. Questionnaires were designed on Google Forms, and then the links were forwarded to the subjects of the study to access them and respond to the items of the questionnaires. The sample of the study consisted of 139 students $(27$ males \& 112 females) and 32 instructors (19 males \& 13 females) from both universities. The questionnaires were given to a jury of EFL experts to validate their items. The experts' reports included some notes and recommendations which were taken into account by the researchers before forwarding the final copy of the questionnaires to the participants of the study. The researchers used Cronbach's alpha coefficient to calculate the reliability of both questionnaires. Reliability of the instructors' questionnaire scored $85.3 \%$ while that of the students scored $87.3 \%$. Finally, the researchers used the SPSS program to analyze the data of the study. The researchers used the following scores to identify the degrees of the means of the participants' responses. These scores are usually used in educational researches to identify the degree of the presence or the absence of a specific phenomenon. The researchers used these scores in most of their papers that are published in reputable blind refereed journals.

- $\quad 1.66-2.66=$ Low Degree

- $\quad$ 2.67-3.67 =Medium Degree

- 3.68 or more $=$ High Degree

\section{Results of the Study}

This section shows the answers to the questions of the study.

Question One: To what extent did the online applications utilized in both universities meet the agreed-upon benchmarks of online learning as perceived by instructors and students?

To answer this question the researchers calculated the means and standard deviations of the benchmark domains of both questionnaires. Table (1) below shows the results of the statistical analysis.

Table 1. Means \& Standard deviations of the benchmark domains of both questionnaires

\begin{tabular}{|c|c|c|}
\hline \multirow{2}{*}{ Agreed upon benchmarks Domains } & \multicolumn{2}{|c|}{ Instructors } \\
\cline { 2 - 3 } M & SD \\
\hline Evaluation and Assessment & 3.8839 & .61519 \\
\hline Teaching and learning & 3.8750 & .45285 \\
\hline Faculty support & 3.8500 & .73441 \\
\hline Student Support & 3.7083 & .68784 \\
\hline & \multicolumn{2}{|c|}{ Students } \\
\hline Teaching and Learning & 3.6249 & .51659 \\
\hline Evaluation and Assessment & 3.4233 & .62111 \\
\hline Student Support & 3.3106 & .64867 \\
\hline
\end{tabular}


All means of instructors' domains range from 3.70 to 3.88. The instructors' responses fit into the category of 'high degree' showing that the utilization of the online applications in both universities meets the agreed-upon benchmarks of online learning. However, the students' responses came with a medium degree ranging from 3.62 to 3.31 .

Question Two: To what extent do the items in each domain meet the agreed-upon benchmarks of online learning?

\section{- Teaching and Learning Agreed upon Benchmarks:}

Table 2. Instructors' and the students' means and standard deviations of the $1^{\text {st }}$ domain

\begin{tabular}{|c|c|c|}
\hline \multicolumn{3}{|c|}{ Teaching and Learning Benchmarks } \\
\hline Instructors' responses & $\mathbf{M}$ & SD \\
\hline The instructor makes efficient use of class time. & 4.25 & .718 \\
\hline $\begin{array}{l}\text { The instructor provides a clear explanation with } \\
\text { sufficient examples. }\end{array}$ & 4.25 & .672 \\
\hline $\begin{array}{l}\text { Student interaction with faculty is facilitated } \\
\text { through a variety of ways. }\end{array}$ & 4.03 & .474 \\
\hline $\begin{array}{l}\text { Emails, Facebook pages, and WhatsApp are } \\
\text { provided to encourage students to work with } \\
\text { each other and with their instructors. }\end{array}$ & 3.84 & 1.110 \\
\hline $\begin{array}{l}\text { Student interaction with other students is } \\
\text { facilitated through a variety of ways. }\end{array}$ & 3.81 & .644 \\
\hline $\begin{array}{l}\text { Course materials promote collaboration among } \\
\text { students. }\end{array}$ & 3.63 & .793 \\
\hline $\begin{array}{l}\text { Courses are designed to require students to } \\
\text { work in groups utilizing problem-solving } \\
\text { activities. }\end{array}$ & 3.31 & .998 \\
\hline \multicolumn{3}{|l|}{ Students' responses } \\
\hline $\begin{array}{l}\text { Emails, Facebook pages, and WhatsApp are } \\
\text { provided to encourage students to work with } \\
\text { each other and with their instructors. }\end{array}$ & 3.99 & .881 \\
\hline $\begin{array}{l}\text { Student interaction with other students is } \\
\text { facilitated through a variety of ways. }\end{array}$ & 3.75 & .723 \\
\hline The instructor makes efficient use of class time. & 3.62 & .846 \\
\hline $\begin{array}{l}\text { Student interaction with faculty is facilitated } \\
\text { through a variety of ways. }\end{array}$ & 3.58 & .833 \\
\hline $\begin{array}{l}\text { The instructor provides a clear explanation with } \\
\text { sufficient examples. }\end{array}$ & 3.54 & 1.044 \\
\hline $\begin{array}{l}\text { Courses are designed to require students to } \\
\text { work in groups utilizing problem-solving } \\
\text { activities. }\end{array}$ & 3.47 & .871 \\
\hline $\begin{array}{l}\text { Course materials promote collaboration among } \\
\text { students. }\end{array}$ & 3.42 & .859 \\
\hline
\end{tabular}

Table (2) above shows that teachers think that all items meet the agreed-upon benchmarks of online learning with a high degree except for the item ' Courses are designed to require students to work in groups utilizing problem-solving activities' which scored a medium degree (3.31). Instructors' responses confirmed that they made efficient use of class time, provided a clear explanation with sufficient examples, and facilitated students' interaction using varied methods. Student's responses showed that the two items ' Emails, Facebook pages, and WhatsApp are provided to encourage students to work with each other and with their instructors' and ' Student interaction with other students is facilitated through a variety of ways ' scored high degrees while the other items scored medium degrees. The item 'Course materials promote collaboration among students' scored the lowest medium degree (3.42).

\section{Student Support Benchmarks}

Table 3. Instructors' and the students' means and standard deviations of the $2^{\text {nd }}$ domain

\begin{tabular}{|c|c|c|}
\hline \multicolumn{3}{|l|}{ Student Support Benchmarks } \\
\hline Instructors' responses & $\mathbf{M}$ & SD \\
\hline $\begin{array}{l}\text { Students can obtain assistance to help them use } \\
\text { electronically accessed data successfully. }\end{array}$ & 3.97 & .695 \\
\hline $\begin{array}{l}\text { Learning outcomes for each course are } \\
\text { summarized in clearly written statements. }\end{array}$ & 3.88 & .793 \\
\hline $\begin{array}{l}\text { Written information is supplied to the student } \\
\text { about online applications. }\end{array}$ & 3.75 & .880 \\
\hline $\begin{array}{l}\text { Easily accessible technical assistance is } \\
\text { available to all students throughout the semester. }\end{array}$ & 3.56 & 1.076 \\
\hline $\begin{array}{l}\text { A structured system is in place to address } \\
\text { students' complaints. }\end{array}$ & 3.56 & 1.014 \\
\hline $\begin{array}{l}\text { Students are provided with hands-on training to } \\
\text { use online applications. }\end{array}$ & 3.53 & 1.077 \\
\hline \multicolumn{3}{|l|}{ Students' responses } \\
\hline $\begin{array}{l}\text { Students can obtain assistance to help them use } \\
\text { electronically accessed data successfully. }\end{array}$ & 3.48 & .981 \\
\hline $\begin{array}{l}\text { Learning outcomes for each course are } \\
\text { summarized in clearly written statements. }\end{array}$ & 3.39 & 1.004 \\
\hline $\begin{array}{l}\text { Written information is supplied to the student } \\
\text { about online applications. }\end{array}$ & 3.38 & .928 \\
\hline $\begin{array}{l}\text { Easily accessible technical assistance is } \\
\text { available to all students throughout the semester. }\end{array}$ & 3.22 & .993 \\
\hline $\begin{array}{l}\text { A structured system is in place to address } \\
\text { students' complaints. }\end{array}$ & 3.21 & 1.053 \\
\hline $\begin{array}{l}\text { Students are provided with hands-on training to } \\
\text { use online applications. }\end{array}$ & 3.18 & 1.030 \\
\hline
\end{tabular}

In table (3), the responses of instructors and students are so similar and have the same order with a slight difference in degrees. The items 'Students can obtain assistance to help them use electronically accessed data successfully', 'Learning outcomes for each course are summarized in clearly written statements' and 'Written information is supplied to the student about the online applications' scored high degrees while the items 'Easily accessible technical assistance is available to all students throughout the semester', 'A structured system is in place to address students' complaints ' and 'Students are provided with hands-on training to use the online applications' scored medium degrees. In the students' questionnaire, the same items appeared in the same order scoring medium degrees. 
Table 4. Instructors' and the students' means and standard deviations of the $3^{\text {rd }}$ domain

\begin{tabular}{|c|c|c|}
\hline Evaluation and Assessment Benchmarks & & \\
\hline Instructors' responses & $\mathbf{M}$ & SD \\
\hline $\begin{array}{l}\text { The instructor's feedback is offered in a } \\
\text { constructive non-threatening manner }\end{array}$ & 4.19 & .592 \\
\hline $\begin{array}{l}\text { Online learning requires students to engage } \\
\text { themselves in analysis, synthesis, and } \\
\text { evaluation as part of their course assignments. }\end{array}$ & 4.00 & .880 \\
\hline $\begin{array}{l}\text { The instructor's feedback to learners' } \\
\text { questions/assignments is provided on time. }\end{array}$ & 3.97 & .647 \\
\hline $\begin{array}{l}\text { An evaluation process is used to improve the } \\
\text { teaching/learning process. }\end{array}$ & 3.91 & .893 \\
\hline $\begin{array}{l}\text { Specific standards are in place to compare and } \\
\text { improve learning outcomes. }\end{array}$ & 3.78 & .975 \\
\hline $\begin{array}{l}\text { Intended learning outcomes are regularly } \\
\text { reviewed. }\end{array}$ & 3.78 & .975 \\
\hline $\begin{array}{l}\text { Data on the best technological practices are } \\
\text { used to evaluate the course effectiveness. }\end{array}$ & 3.56 & .982 \\
\hline \multicolumn{3}{|l|}{ Students' responses } \\
\hline $\begin{array}{l}\text { Online learning requires students to engage } \\
\text { themselves in analysis, synthesis, and } \\
\text { evaluation as part of their course assignments. }\end{array}$ & 3.62 & .974 \\
\hline $\begin{array}{l}\text { The instructor's feedback to learners' } \\
\text { questions/assignments is provided on time. }\end{array}$ & 3.50 & 1.003 \\
\hline $\begin{array}{l}\text { Specific standards are in place to compare and } \\
\text { improve learning outcomes. }\end{array}$ & 3.40 & .890 \\
\hline $\begin{array}{l}\text { An evaluation process is used to improve the } \\
\text { learning process. }\end{array}$ & 3.37 & 1.037 \\
\hline $\begin{array}{l}\text { The instructor's feedback is offered in a } \\
\text { constructive non-threatening manner. }\end{array}$ & 3.36 & 1.000 \\
\hline $\begin{array}{l}\text { Intended learning outcomes are regularly } \\
\text { reviewed. }\end{array}$ & 3.29 & .829 \\
\hline
\end{tabular}

Table (4) shows that all instructors' items in this domain scored high degrees except for the item 'Data on the best technological practices are used to evaluate the course effectiveness'. However, all students' items scored medium degrees with means ranging from 3.62 to 3.29 .

Table 5. Instructors' means and standard deviations of the 'Faculty Support Agreed upon benchmarks '

\begin{tabular}{|l|c|c|}
\hline \multicolumn{1}{|c|}{ Faculty Support Benchmarks } & M & SD \\
\hline $\begin{array}{l}\text { Adequate technical assistance is available to } \\
\text { faculty. }\end{array}$ & 4.09 & .734 \\
\hline $\begin{array}{l}\text { Faculty members are assisted in the transition } \\
\text { from classroom teaching to online teaching. }\end{array}$ & 4.03 & .897 \\
\hline $\begin{array}{l}\text { Online training continues throughout the } \\
\text { progression of the online class. }\end{array}$ & 3.91 & .928 \\
\hline $\begin{array}{l}\text { There are peer mentoring resources available to } \\
\text { faculty members teaching online. }\end{array}$ & 3.63 & 1.157 \\
\hline $\begin{array}{l}\text { Faculty members are provided with written } \\
\text { resources to deal with issues arising from } \\
\text { student use of online applications. }\end{array}$ & 3.59 & 1.103 \\
\hline
\end{tabular}

As seen in table (5), instructors' responses showed that the items 'Adequate technical assistance is available to faculty', 'Faculty members are assisted in the transition from classroom teaching to online teaching 'and 'Online training continues throughout the progression of the online class' scored high degrees while the items 'There are peer mentoring resources available to faculty members teaching online' and the item 'Faculty members are provided with written resources to deal with issues arising from student use of online applications' scored medium degrees.

Question Three: How do EFL instructors and learners perceive the integration of online components into the process of teaching and learning?

\section{- EFL Instructors' Responses}

The table below shows the EFL instructors' responses to the domain 'Instructors' General Perceptions'.

Table 6. Means and standard deviations to the domain 'Instructors' General Perceptions'

\begin{tabular}{|l|c|c|}
\hline \multicolumn{1}{|c|}{ Instructors' General Perceptions } & M & SD \\
\hline $\begin{array}{l}\text { Face-to-face classes combined with an online } \\
\text { experience is an advantage. }\end{array}$ & 4.44 & .716 \\
\hline $\begin{array}{l}\text { Online education provides a valuable teaching } \\
\text { experience }\end{array}$ & 4.25 & .842 \\
\hline $\begin{array}{l}\text { Online teaching takes more time than classroom } \\
\text { teaching. }\end{array}$ & 4.00 & 1.191 \\
\hline $\begin{array}{l}\text { The online education is flexible enough to meet } \\
\text { my needs. }\end{array}$ & 3.94 & .801 \\
\hline $\begin{array}{l}\text { I recommend online courses to other } \\
\text { instructors. }\end{array}$ & 3.88 & .942 \\
\hline $\begin{array}{l}\text { I find online sessions convenient and } \\
\text { interesting. }\end{array}$ & 3.81 & .965 \\
\hline $\begin{array}{l}\text { Online courses enhance the quality of our } \\
\text { university's reputation. }\end{array}$ & 3.72 & 1.023 \\
\hline $\begin{array}{l}\text { Students have adequate time to participate } \\
\text { effectively in online courses. }\end{array}$ & 3.53 & 1.047 \\
\hline $\begin{array}{l}\text { Completely face-to-face teaching is an } \\
\text { advantage. }\end{array}$ & 3.44 & 1.366 \\
\hline $\begin{array}{l}\text { The absence of face-to-face interaction with } \\
\text { students is a disadvantage. }\end{array}$ & 3.41 & 1.241 \\
\hline $\begin{array}{l}\text { There is inadequate time to learn about online } \\
\text { teaching. }\end{array}$ & 3.09 & 1.091 \\
\hline $\begin{array}{l}\text { My colleagues talk negatively about online } \\
\text { teaching. }\end{array}$ & 1.295 \\
\hline $\begin{array}{l}\text { Completely online teaching is a disadvantage. } \\
\text { teaching are confusing. }\end{array}$ & 1.216 \\
\hline $\begin{array}{l}\text { There is adequate time to prepare for online } \\
\text { courses. }\end{array}$ & $\begin{array}{l}\text { online instruction. } \\
\text { providing a valuable teaching experience. }\end{array}$ \\
\hline $\begin{array}{l}\text { I could deal with the online course more easily } \\
\text { than unfamiliar with effective methods of }\end{array}$ & 1.167 \\
\hline
\end{tabular}

In table (6), instructors' responses scored high degrees ranging from 4.44 to 3.72 for the items that emphasize the advantages of blended learning and that online education provided learners with valuable experience though it takes more time than classroom teaching. They also confirmed that online education was flexible, convenient, and interesting to the extent that it enhances the quality of their university reputation. All other items came with medium degrees ranging from 3.53 to 2.84 except for the items 'I am unfamiliar with effective methods of online instruction' and 'The web applications involved in online teaching are confusing' which scored low degrees.

\section{EFL Students' Responses}

The table below shows the EFL students' responses to 
the domain 'Students' General Perceptions'.

Table 7. Means and standard deviations of the domain 'Students' General Perceptions'

\begin{tabular}{|c|c|c|}
\hline Students' General Perceptions & $\mathbf{M}$ & SD \\
\hline $\begin{array}{l}\text { Completely face-to-face learning is an } \\
\text { advantage. }\end{array}$ & 3.78 & .946 \\
\hline $\begin{array}{l}\text { The face-to-face class combined with an } \\
\text { online experience is an advantage. }\end{array}$ & 3.75 & .991 \\
\hline $\begin{array}{l}\text { My classmates talk negatively about online } \\
\text { teaching. }\end{array}$ & 3.64 & 1.070 \\
\hline $\begin{array}{l}\text { The absence of face-to-face interaction with } \\
\text { teachers is a disadvantage. }\end{array}$ & 3.41 & 1.166 \\
\hline $\begin{array}{l}\text { There is adequate time to prepare for online } \\
\text { courses. }\end{array}$ & 3.36 & .979 \\
\hline $\begin{array}{l}\text { There is inadequate time to learn about } \\
\text { online learning. }\end{array}$ & 3.30 & .946 \\
\hline $\begin{array}{l}\text { Online learning provides a valuable learning } \\
\text { experience. }\end{array}$ & 3.30 & 1.033 \\
\hline $\begin{array}{l}\text { Online learning takes more time than } \\
\text { classroom learning. }\end{array}$ & 3.29 & 1.299 \\
\hline $\begin{array}{l}\text { Students have adequate access to participate } \\
\text { effectively in online courses. }\end{array}$ & 3.20 & 1.145 \\
\hline $\begin{array}{l}\text { Online courses enhance the quality of our } \\
\text { university reputation. }\end{array}$ & 3.20 & 1.059 \\
\hline $\begin{array}{l}\text { The web applications involved in online } \\
\text { learning are confusing. }\end{array}$ & 3.15 & 1.025 \\
\hline $\begin{array}{l}\text { There is adequate technical support for } \\
\text { online learning. }\end{array}$ & 3.14 & 1.082 \\
\hline $\begin{array}{l}\text { I find online sessions convenient and } \\
\text { interesting. }\end{array}$ & 3.00 & 1.251 \\
\hline $\begin{array}{l}\text { The online learning was flexible enough to } \\
\text { meet my needs. }\end{array}$ & 2.99 & 1.260 \\
\hline $\begin{array}{l}\text { I recommend online courses to other } \\
\text { students. }\end{array}$ & 2.97 & 1.285 \\
\hline $\begin{array}{l}\text { Completely online learning is a } \\
\text { disadvantage. }\end{array}$ & 2.94 & 1.243 \\
\hline $\begin{array}{l}\text { I could deal with the online course more } \\
\text { easily than face-to-face courses. }\end{array}$ & 2.81 & 1.191 \\
\hline
\end{tabular}

Table (7) above shows that the items 'Completely face-to-face learning is an advantage' and 'Face-to-face class combined with an online experience is an advantage' scored high degree. All other items scored medium degrees starting from the item 'My classmates talk negatively about online teaching ' with a mean of 3.64, to the item 'I could deal with the online course more easily than face-to-face courses ' with a mean of 2.81 .

Question Four: Are there any statistically significant differences at the level of significance $(\alpha \leq 0.05)$ in the instructors' responses due to gender, university, and age?

To find whether the differences in means are statistically significant, the researchers used a T-test for gender and university variables and ANOVA for the age variable.

\section{- Gender}

The table below shows the results of the T-test that investigates the significance of the differences in means due to instructors' gender.
Table 8. Results of the Independent Samples Test of the gender variable

\begin{tabular}{|c|c|c|c|c|c|}
\hline & Gender & N & M & SD & $\begin{array}{c}\text { Sig. } \\
\text { (2-tailed) }\end{array}$ \\
\hline $\begin{array}{c}\text { Teaching and } \\
\text { learning } \\
\text { benchmarks }\end{array}$ & Male & 19 & 4.0075 & .35146 & .043 \\
\cline { 2 - 6 } & Female & 13 & 3.6813 & .52539 & .065 \\
\hline $\begin{array}{c}\text { Student Support } \\
\text { benchmarks }\end{array}$ & Male & 19 & 3.7807 & .60106 & .481 \\
\cline { 2 - 6 } & Female & 13 & 3.6026 & .81234 & .508 \\
\hline $\begin{array}{c}\text { Evaluation and } \\
\text { Assessment } \\
\text { benchmarks }\end{array}$ & Male & 19 & 3.9098 & .58556 & .779 \\
\cline { 2 - 6 } & Female & 13 & 3.8462 & .67879 & .786 \\
\hline $\begin{array}{c}\text { Faculty support } \\
\text { bench }\end{array}$ & Male & 19 & 3.8421 & .75301 & .943 \\
\cline { 2 - 6 } & Female & 13 & 3.8615 & .73659 & .943 \\
\hline \multirow{2}{*}{\begin{tabular}{c} 
General Attitude \\
\cline { 2 - 6 }
\end{tabular}} & Fale & 19 & 3.4520 & .34470 & .971 \\
\hline
\end{tabular}

Table (7) shows that there are no statistically significant differences between the means of instructors' responses in all domains except for the 'Teaching and Learning benchmarks ' domain for the favor of male instructors.

\section{- University}

Table (9) shows the results of the T-test that investigates the significance of the differences in means due to university instructors.

Table 9. Results of the Independent Samples Test of the university variable

\begin{tabular}{|c|c|c|c|c|c|}
\hline & University & $\mathbf{N}$ & Mean & SD & $\begin{array}{c}\text { Sig. } \\
\text { (2-tailed) }\end{array}$ \\
\hline \multirow{2}{*}{$\begin{array}{c}\text { Teaching and } \\
\text { learning }\end{array}$} & $\begin{array}{c}\text { Ahliya } \\
\text { University }\end{array}$ & 12 & 3.9762 & .48285 & .336 \\
\cline { 2 - 6 } & $\begin{array}{c}\text { Hebron } \\
\text { University }\end{array}$ & 20 & 3.8143 & .43504 & .351 \\
\hline \multirow{2}{*}{ Student Support } & $\begin{array}{c}\text { Ahliya } \\
\text { University }\end{array}$ & 12 & 4.0139 & .76362 & .050 \\
\cline { 2 - 6 } & $\begin{array}{c}\text { Hebron } \\
\text { University }\end{array}$ & 20 & 3.5250 & .58308 & .072 \\
\hline \multirow{2}{*}{$\begin{array}{c}\text { Evaluation and } \\
\text { Assessment }\end{array}$} & $\begin{array}{c}\text { Ahliya } \\
\text { University }\end{array}$ & 12 & 4.0833 & .68771 & .159 \\
\cline { 2 - 6 } & $\begin{array}{c}\text { Hebron } \\
\text { University }\end{array}$ & 20 & 3.7643 & .55090 & .188 \\
\hline \multirow{2}{*}{ Faculty support } & $\begin{array}{c}\text { Ahliya } \\
\text { University }\end{array}$ & 12 & 4.1000 & .78855 & .138 \\
\cline { 2 - 6 } & $\begin{array}{c}\text { Hebron } \\
\text { University }\end{array}$ & 20 & 3.7000 & .67590 & .158 \\
\hline \multirow{2}{*}{$\begin{array}{c}\text { General } \\
\text { Attitude }\end{array}$} & $\begin{array}{c}\text { Ahliya } \\
\text { University }\end{array}$ & 12 & 3.5686 & .42220 & .176 \\
\cline { 2 - 6 } & $\begin{array}{c}\text { Hebron } \\
\text { University }\end{array}$ & 20 & 3.3853 & .32246 & .211 \\
\hline
\end{tabular}

As seen in table (9), an analysis of variance showed statistically significant differences between the means of instructors' responses in the domain 'Student Support' for the favor of Palestine Ahliya University $(\mathrm{M}=4.01, \mathrm{SD}$ $=.76)$, sig $=.05$ while other domains showed no statistically significant differences at the level of significance $(\alpha \leq 0.05)$.

Age

To find out whether there are statistically significant 
differences between the means of instructors' responses due to the age variable, the researchers used the ANOVA test.

Table 10. Results of the ANOVA test of the age variable

\begin{tabular}{|c|c|c|c|c|c|c|}
\hline \multicolumn{2}{|c|}{ Agreed upon benchmarks } & \begin{tabular}{|c|} 
Sum of \\
Squares
\end{tabular} & Df & \begin{tabular}{|c|} 
Mean \\
Square
\end{tabular} & $\mathbf{F}$ & Sig. \\
\hline \multirow{3}{*}{$\begin{array}{l}\text { Teaching and } \\
\text { learning } \\
\text { benchmarks }\end{array}$} & $\begin{array}{c}\text { Between } \\
\text { Groups }\end{array}$ & 1.639 & 3 & .546 & 1.243 & .821 \\
\hline & $\begin{array}{c}\text { Within } \\
\text { Groups }\end{array}$ & 12.299 & 28 & .439 & & \\
\hline & Total & 13.938 & 31 & & & \\
\hline \multirow{3}{*}{$\begin{array}{l}\text { Student Support } \\
\text { benchmarks }\end{array}$} & $\begin{array}{c}\text { Between } \\
\text { Groups }\end{array}$ & 4.130 & 3 & 1.377 & 3.658 & .024 \\
\hline & $\begin{array}{c}\text { Within } \\
\text { Groups }\end{array}$ & 10.537 & 28 & .376 & & \\
\hline & Total & 14.667 & 31 & & & \\
\hline \multirow{3}{*}{$\begin{array}{c}\text { Evaluation and } \\
\text { Assessment } \\
\text { benchmarks }\end{array}$} & $\begin{array}{c}\text { Between } \\
\text { Groups }\end{array}$ & 1.141 & 3 & .380 & 1.005 & .405 \\
\hline & $\begin{array}{l}\text { Within } \\
\text { Groups }\end{array}$ & 10.591 & 28 & .378 & & \\
\hline & Total & 11.732 & 31 & & & \\
\hline \multirow{3}{*}{$\begin{array}{l}\text { Faculty support } \\
\text { bench }\end{array}$} & $\begin{array}{c}\text { Between } \\
\text { Groups }\end{array}$ & .186 & 3 & .062 & .105 & .956 \\
\hline & $\begin{array}{l}\text { Within } \\
\text { Groups }\end{array}$ & 16.534 & 28 & .590 & & \\
\hline & Total & 16.720 & 31 & & & \\
\hline \multirow{3}{*}{ General Attitude } & $\begin{array}{c}\text { Between } \\
\text { Groups }\end{array}$ & .188 & 3 & .063 & .439 & .727 \\
\hline & $\begin{array}{l}\text { Within } \\
\text { Groups }\end{array}$ & 4.000 & 28 & .143 & & \\
\hline & Total & 4.188 & 31 & & & \\
\hline
\end{tabular}

As seen in table (10) above, a statistically significant difference was traced for the 'Student Support benchmark' with a significance of $(0.042)$. Moreover, the statistical analysis results show that the instructors' age (40-50) scored the highest mean (3.393). To find the source of the significance that appeared in table (10), the researchers used the Scheffe test as seen in table (11) below.

Table 11. Results of Scheffe Test

\begin{tabular}{|c|c|c|c|c|c|}
\hline $\begin{array}{c}\text { Dependent } \\
\text { Variable }\end{array}$ & Age & $\mathbf{3 0 - 4 0}$ & $\mathbf{4 0 - 5 0}$ & $\mathbf{5 0 - 6 0}$ & $\mathbf{6 0 +}$ \\
\hline \multirow{3}{*}{$\begin{array}{c}\text { Student } \\
\begin{array}{c}\text { Support } \\
\text { benchmarks }\end{array}\end{array}$} & $30-40$ & --- & $.77949 * *$ & .67949 & .17949 \\
\cline { 2 - 6 } & $40-50$ & & --- & .10000 & .60000 \\
\cline { 2 - 6 } & $50-60$ & & & --- & .50000 \\
\cline { 2 - 6 } & $60+$ & & & & --- \\
\hline
\end{tabular}

Post hoc analyses using the Scheffé post hoc criterion for significance indicated that the source of the significance in the benchmark 'Student Support' was for the favor of instructors whose ages are from 40-50 years old (sig..77949).

Question Five: Are there any statistically significant differences at the level of significance $(\alpha \leq 0.05)$ in the students' responses due to university, gender, and year of study?

To find whether the differences in means are statistically significant, the researchers used a T-test for university and gender variables and ANOVA for the year of study variable.

\section{- University}

The table below shows the results of the T-test that investigates the significance of the differences in means due to students' university.

Table 12. Results of the Independent Samples Test of the university variable

\begin{tabular}{|c|c|c|c|c|c|}
\hline Domain & University & $\mathbf{N}$ & $\mathbf{M}$ & SD & Sig. \\
\hline \multirow{2}{*}{$\begin{array}{c}\text { Teaching and } \\
\text { Learning }\end{array}$} & $\begin{array}{c}\text { Ahliya } \\
\text { University }\end{array}$ & 48 & 3.6161 & .46141 & .885 \\
\cline { 2 - 6 } & $\begin{array}{c}\text { Hebron } \\
\text { University }\end{array}$ & 91 & 3.6295 & .54585 & .879 \\
\hline \multirow{2}{*}{ Student Support } & $\begin{array}{c}\text { Ahliya } \\
\text { University }\end{array}$ & 48 & 3.4167 & .61885 & .162 \\
\cline { 2 - 6 } & $\begin{array}{c}\text { Hebron } \\
\text { University }\end{array}$ & 91 & 3.2546 & .66031 & .155 \\
\hline \multirow{2}{*}{ Evaluation and } \\
Assessment & $\begin{array}{c}\text { Ahliya } \\
\text { University }\end{array}$ & 48 & 3.3507 & .61140 & .319 \\
\cline { 2 - 6 } & $\begin{array}{c}\text { Hebron } \\
\text { University }\end{array}$ & 91 & 3.4615 & .62612 & .316 \\
\hline \multirow{2}{*}{ General Attitude } & $\begin{array}{c}\text { Ahliya } \\
\text { University }\end{array}$ & 48 & 3.2953 & .43132 & .404 \\
\cline { 2 - 6 } & $\begin{array}{c}\text { Hebron } \\
\text { University }\end{array}$ & 91 & 3.2288 & .45323 & .398 \\
\hline
\end{tabular}

As table (12) shows, there were no statistically significant differences between the means of students' responses due to university variable.

\section{Gender}

The table below shows the results of the T-test that investigates the significance of the differences in means due to students' gender.

Table 13. Results of the Independent Samples Test of the Gender Variable

\begin{tabular}{|c|c|c|c|c|c|}
\hline Benchmark & Gender & $\mathbf{N}$ & $\mathbf{M}$ & SD & Sig. \\
\hline \multirow{2}{*}{$\begin{array}{c}\text { Teaching and } \\
\text { Learning }\end{array}$} & Male & 27 & 3.4656 & .50210 & .074 \\
\cline { 2 - 6 } & Female & 112 & 3.6633 & .51485 & .075 \\
\hline \multirow{2}{*}{\begin{tabular}{c} 
Student Support \\
\cline { 2 - 6 }
\end{tabular}} & Male & 27 & 3.2840 & .56579 & .813 \\
\hline \multirow{2}{*}{$\begin{array}{c}\text { Evaluation and } \\
\text { Assessment }\end{array}$} & Female & 112 & 3.3170 & .66927 & .794 \\
\cline { 2 - 6 } & Female & 112 & 3.4405 & .63034 & .492 \\
\hline \multirow{2}{*}{\begin{tabular}{c} 
General Attitude \\
\cline { 2 - 6 }
\end{tabular}} & Male & 27 & 3.2854 & .57744 & .664 \\
\cline { 2 - 6 } & Female & 112 & 3.2437 & .41005 & .725 \\
\hline
\end{tabular}

An analysis of variance showed no statistically significant differences between the means of students' responses due to gender.

\section{Year of study}

To find out whether there are statistically significant differences between the means of instructors' responses due to the age variable, the researchers used the ANOVA test. 
Table 14. Results of the ANOVA test of the year of study variable

\begin{tabular}{|c|c|c|c|c|c|c|}
\hline \multicolumn{2}{|c|}{ Agreed upon benchmarks } & \multirow{2}{*}{$\begin{array}{c}\begin{array}{c}\text { Sum of } \\
\text { Squares }\end{array} \\
.404\end{array}$} & \multirow{2}{*}{$\begin{array}{c}\text { Df } \\
2\end{array}$} & \multirow{2}{*}{\begin{tabular}{|c|}
$\begin{array}{c}\text { Mean } \\
\text { Square }\end{array}$ \\
.202 \\
\end{tabular}} & \multirow{2}{*}{$\begin{array}{c}\mathbf{F} \\
.753\end{array}$} & \multirow{2}{*}{$\begin{array}{l}\text { Sig. } \\
.473\end{array}$} \\
\hline \multirow{3}{*}{$\begin{array}{c}\text { Teaching and } \\
\text { Learning }\end{array}$} & $\begin{array}{l}\text { Between } \\
\text { Groups }\end{array}$ & & & & & \\
\hline & $\begin{array}{l}\text { Within } \\
\text { Groups }\end{array}$ & 36.424 & 136 & .268 & & \\
\hline & Total & 36.827 & 138 & & & \\
\hline \multirow{3}{*}{$\begin{array}{l}\text { Student } \\
\text { Support }\end{array}$} & $\begin{array}{c}\text { Between } \\
\text { Groups }\end{array}$ & .276 & 2 & .138 & .325 & .723 \\
\hline & $\begin{array}{l}\text { Within } \\
\text { Groups }\end{array}$ & 57.791 & 136 & .425 & & \\
\hline & Total & 58.067 & 138 & & & \\
\hline \multirow{3}{*}{$\begin{array}{c}\text { Evaluation and } \\
\text { Assessment }\end{array}$} & $\begin{array}{c}\text { Between } \\
\text { Groups }\end{array}$ & .858 & 2 & .429 & 1.114 & .331 \\
\hline & $\begin{array}{l}\text { Within } \\
\text { Groups }\end{array}$ & 52.379 & 136 & .385 & & \\
\hline & Total & 53.237 & 138 & & & \\
\hline \multirow{3}{*}{$\begin{array}{l}\text { General } \\
\text { Attitude }\end{array}$} & $\begin{array}{c}\text { Between } \\
\text { Groups }\end{array}$ & .323 & 2 & .161 & .811 & .447 \\
\hline & $\begin{array}{l}\text { Within } \\
\text { Groups }\end{array}$ & 27.048 & 136 & .199 & & \\
\hline & Total & 27.370 & 138 & & & \\
\hline
\end{tabular}

\section{Conclusions}

In response to the first question that investigates the extent to which the online applications utilized in both universities meet the agreed-upon benchmarks of online learning from instructors' and students' views, all instructors' responses scored high degrees while the students' ones scored medium degrees. Researchers think that this difference in degrees between teachers' and students' responses reflects the reality and the state of affairs regarding the application of online learning. Students are the ones who suffer more from the extra burdens imposed on them as a result of utilizing online learning. Moreover, instructors' response to the 'evaluation and assessment' benchmark domain ranked first with a mean of (3. 88) while students' responses ranked second with a medium degree (3.42). This can be attributed to students' dissatisfaction with the tools or the assignments and activities they are assessed against. Researchers think that traditional assessment should be substituted with alternative assessment that enables students to be more involved and active.

Upon investigating the extent to which each item in each domain meets the agreed-upon benchmarks of online learning, results showed a difference in the degrees between these items as perceived by instructors and students. For example, instructors' responses showed that the items 'The instructor made efficient use of class time', 'The instructor provided clear explanation with sufficient examples', and 'Student interaction with faculty is facilitated through a variety of ways' scored high degrees with means of $(4.25,4.25,4.03)$ respectively. On the other hand, students' responses to the same items scored medium degrees with means of $(3.62,3.58,3.54)$ respectively. This means that students think that instructors do not use class time efficiently to the same degree as instructors believe. They don't also think that instructors always provide a clear explanation or facilitate their interaction in varied ways.

As for the Student Support Agreed upon benchmarks, instructors and students ranked the items in the same order with a slight difference in degrees. Instructors' responses scored high degrees for the first three items while students gave them medium degrees. Hence, students do not share their teachers' views regarding the electronic assistance they obtain and the learning outcomes for each course are summarized in clearly written statements. The same can be noticed in 'Evaluation and Assessment Benchmark' in which instructors' responses gave high degrees to the items related to providing feedback in a constructive and non-threatening manner and that learning requires students' engagements in analysis, synthesis, and evaluation. Nevertheless, students gave these two items medium degrees. This reflects the fact that teachers sometimes overestimate their positive role in the process of teaching and learning. Regarding 'Faculty Support Benchmark', instructors showed their satisfaction with the services provided by both universities as most of the items scored high degrees.

EFL instructors' perception of utilizing online components into the process of teaching and learning scored medium degrees and some of the items scored high degrees. As seen in table (6) above, the first seven items scored high degrees. For example, instructors recommended having blended learning as they consider it as an advantage with a mean of (4.44); they also believe that online education provided them with valuable teaching experience with a mean of (4.25). Responses also emphasized the fact that online learning is convenient, interesting, and flexible but needs much time. Researchers do believe that flexibility is an advantage that enables teachers and students to choose the place, the time, and the pace that are in harmony with students' levels and capabilities. Instructors' responses showed that they are familiar with the methods of online instruction and that it is not confusing. This appears in the last two items that scored low degrees.

The instructors aged 40 to 50 are more aware of their students' needs. This means that they provide more support and help to students during this new mode of teaching and learning. This might be attributed to the fact that this group of instructors are better qualified and have more technological and educational competencies that enable them to successfully overcome most obstacles they may face while teaching online.

As for the students' perceptions, priorities have been changed to some extent. They think that completely face-to-face learning is an advantage as it is ranked first with a mean of (3.78) followed by the item 'Face-to-face 
class combined with an online experience is an advantage ' that scored a high degree with a mean of (3.75). This can be attributed to the fact that face-to-face mode is the best in their views, and in case of emergency blended learning can be a good choice. All of the other items scored medium degrees. For example, the item 'I could deal with the online course more easily than face-to-face courses' scored a medium degree with a mean of (2.81). These results support their answers to the first item as they prefer face-to-face learning rather than completely online learning. Students' year of study does not affect their responses in all domains. This means that all students share the same attitude and the same perception towards the utilization of online teaching and learning using varied web applications.

\section{REFERENCES}

[1] M. Hamayil, F. Ghanem. Management Role of Al-Quds Open University in Leading Effective Distance Learning Programs: An Evaluation of QOU Experience in Blended Learning. Al-Quds Open University, Palestine. CONTEMPORARY EDUCATIONAL TECHNOLOGY, 2011, 2(1), 55-76

[2] ZOOM website. Retrieved from https://zoom.us/

[3] Tech.Terms. Retrieved from: https://techterms.com/definiti on/moodle\#: :text=Moodle $\% 20$ is $\% 20$ an $\% 20$ acronym $\% 20 \mathrm{f}$ or,interact $\% 20$ with $\% 20$ teachers $\% 20$ and $\% 20$ students.

[4] K. Bell. Student's Quick Guide to Google Classroom, Shake UP Learning LLC, 2015 Retrieved fromhttp://www.santees d.net/cms/lib/CA01000468/Centricity/Domain/289/Student \%20Quick\%20Guide\%20to\%20Google\%20Classroom.pdf

[5] GSuite for Education. URL https://edu.google.com/product s/gsuite-for-education/?modal_active=none

[6] J. Ayoub. Effective Use of ZOOM Sessions (a Synchronous Learning Strategy) to Foster Success and Motivation of Lebanese University Students in Bekaa: A Case Study. Awraq Thaqafya Journal, 1 (4), 2020. ISSN26634408. Retrieved from http//www.awraqthaqafya.com.

[7] M. Ulla, William F Perales \& V. Tarrayo. Integrating Internet-based applications in English language teaching: Teacher practices in a Thai university. Walailak University, Thailand. Issues in Educational Research, 30(1), 365. 2020

[8] L Fanous. The Impact of Asynchronous and Synchronous e-Feedback on EFL Learners' Writing Skills. Awraq Thaqafya Journal, 1 (4), 2020

i This study is part of an internal grant offered by Palestine Ahliya University
[9] P. Raine. Developing Web-based English Learning Applications: Principles and Practice. CALL-EJ, 19(2), 125-138, 125, J. F. Oberlin University, Tokyo, Japan, 2019.

[10] R. Fithriani, U. Dewi, S. Daulay, M. Salmiah \& W. Fransiska. Using Facebook in EFL Writing Class: Its Effectiveness from the Students' Perspective. DOI: 10.18502/kss.v3i19.4892. (2019). GSuite for Education. Retrieved from https://edu.google.com/products/gsuite-foreducation/?modal_active $=$ none

[11] J. Reinhardt. Social media in second and foreign language teaching and learning: Blogs, wikis, and social networking. Language Teaching, Volume 52, Issue 1, January 2019, pp. 1-39. Retrieved fromhttps://www.cambridge.org/core/journ als/language-teaching/article/abs/social-media-in-second-an d-foreign-language-teaching-and-learning-blogs-wikis-andsocial-networking/9237B4381F7FCBC69C56EB22E6EC5 7DC\#access-block

[12] M. Sayem, B. Tyalor, M. Mcclanachan \& M. Muntahina. Effective use of ZOOM technology and instructional videos to improve engagement and success of distance students in Engineering, CQ University Australia the School of Engineering and Technology a.sayem@cqu.edu.au. AAEE2017 CONFERENCE, Manly, Australia, 2017. Available from: https://www.researchgate.net/publication/3 23268816_Effective_use_of_ZOOM_technology_and_instr uctional_videos_to_improve_engagement_and_success_of distance_students_in_Engineering [accessed Jul 18 2020].

[13] A. Raman \& H. Krishnasamy. Skype In The English Language Classroom, Proceeding - Kuala Lumpur International Communication, Education, Language and Social Sciences 1 (KLiCELS 2), 17 - 2015. Hotel Putra, Kuala Lumpur, Malaysia. Retrieved from: https://www.rese archgate.net/publication/286451914 SKYPE IN THE EN GLISH_LANGUAGE_CLASSROOM

[14] G. Jamalifar \& A. Chalak. The Use of the Internet in English Language Learning: Practices, Attitudes, and Challenges of the Learners. Advances in English Language and Literature (AELL), 1(2), Pp. 1-6, 2014, ISSN: 2328-2711 Ref Number: 1620140501, Retrieved From: Http://Www.Projournals.Org /Aell.

[15] M. Farrah. An Evaluation of an Online English for Academic Writing Program Using the IHEP 2000 Quality Agreed upon benchmarks. Unpublished Ph. D Dissertation, International Islamic University: Malaysia, 2006.

[16] M. Farrah. Quality Benchmarking for Online Writing Course: A Malaysian Case Study. World Applied Sciences Journal 21 (Special Issue of Studies in Language Teaching and Learning): 117-124, 2013. IDOSI Publications. DOI: 10.5829/idosi.wasj.2013.21.slt1.2145.https://www.idosi.org/ wasj/wasj21(SLTL)13/15.pdf?fbclid=IwAR3U6dOZEQhu5 evAEseZ7P88IlMei8dOX0wK1LgKnGBiVB4fENg1BVT Dg8U. 